\title{
PERAWATAN PAYUDARA UNTUK MENCEGAH BENDUNGAN ASI PADA IBU POST PARTUM
}

\author{
Ria Gustirini ${ }^{1}$ \\ 1Prodi DIII Kebidanan Fakultas IImu Kesehatan Institut IImu Kesehatan dan Teknologi \\ Muhammadiyah Palembang, Indonesia
}

\begin{abstract}
The postnatal period is the period after delivery where the mother can give breast milk to her baby. Breastmilk provided exclusively can meet energy and nutritional needs so that babies can grow and develop optimally. One of the causes of not achieving exclusive breastfeeding is that the baby does not get enough milk due to problems in breastfeeding caused by the mother experiencing engorgement. If this situation continues, it can lead to mastitis and breast abscess. One of the efforts to prevent breast milk damages is by breast care. Breast care aims to improve blood circulation and prevent blockage of the milk production channels so as to facilitate milk production. This study aims to analyze the relationship between breast care in preventing breastfeeding in post partum mothers. This research is a descriptive analytic study with a cross sectional research design. Sampling was done by consecutive sampling. Data analysis carried out included univariate and bivariate analyzes. The statistical test used is the Chi-Square Test. The results showed that there was a relationship between breast care and the incidence of engorgement in post partum mothers with a $P$ value of $0.02(p<0.05)$ and an OR value of 8.7 where mothers who did not perform breast care had a risk of 8.75 times greater. Midwives can play a role in preventing the incidence of engorgement by providing counseling and teaching the steps to carry out breast care until the mother understands, understands and is able to carry out care independently
\end{abstract}

Keywords : Breast Care, Breastfeeding, Engorgement, Post Partum Mothers 


\section{PENDAHULUAN}

Air Susu Ibu (ASI) yang diberikan secara eksklusif dapat memenuhi kebutuhan energi dan nutrisi sehingga bayi dapat tumbuh dan berkembang optimal. Berdasarkan data World Health Organization (WHO), sebesar 53\% angka kematian bayi di Indonesia terkait dengan faktor nutrisi. Penyakit yang timbul akibat malnutrisi yaitu diare sebesar 15\% (Kemenkes, 2012)

Bayi yang tidak mendapatkan ASI ekslusif mempunyai risiko kematian akibat diare lebih besar dibandingkan bayi yang mendapat ASI eksklusif. Kematian akibat diare dan pneumonia dapat dikurangi sebesar sepertiga jika bayi diberikan ASI eksklusif(Lamberti et al., 2011)

Persentase pemberian ASI eksklusif pada bayi 0-6 bulan di Indonesia masih rendah yaitu sebesar $54,3 \%$. Persentase pemberian ASI di Sumatera Selatan sebesar $74,49 \%$ dan cakupan pemberian ASI esklusif Kota Palembang tahun 2014 yaitu sebesar 74,18\% (Dinkes, 2014) Capaian ASI eksklusif di Indonesia masih jauh dari target nasional yaitu sebesar 80\%.(Indonesia, 2013)

Salah satu penyebab tidak tercapainya pemberian ASI eksklusif yaitu bayi tidak mendapat ASI yang cukup dikarenakan masalah dalam menyusui yang dikarenakan ibu mengalami engorgement (Bendungan ASI) (Murniati and Kusumawati, 2013). Payudara yang mengalami pembengkakan atau bendungan ASI tersebut sangat sukar disusu oleh bayi karena payudara lebih menonjol, puting lebih datar, dan sukar di hisap oleh bayinya.(Impartina, 2017)

Gejala yang sering muncul pada saat terjadi bendungan ASI antara lain payudara bengkak, payudara terasa panas dan keras dan suhu tubuh ibu sampai 380C. Apabila keadaan ini berlanjut maka dapat mengakibatkan terjadinya mastitis dan abses payudara.(Wulandari et al., 2016)

Berdasarkan data ASEAN tahun 2014 didapatkan bahwa presentase cakupan kasus bendungan ASI pada ibu post partum tercatat sebanyak 107.654 ibu post partum dan pada tahun 2015 ibu yang mengalami bendungan ASI sebanyak 76.543 ibu post partum. Hal ini dikarenakan kurangnya kesadaran ibu post partum dalam memberikan ASI kepada bayinya (Taqiyah et al., 2019)

Salah satu upaya untuk mencegah bendungan ASI yaitu dengan perawatan payudara atau breast care. Perawatan payudara bertujuan untuk melancarkan sirkulasi darah dan mencegah tersumbatnya saluran produksi ASI sehingga memperlancar pengeluaran ASI. Rangsangan taktil saat perawatan payudara dapat menstimulasi hormon prolaktin dan oksitosin yang membantu bayi mendapatkan ASI. (Gustirini and Anggraini, 2020)

Penelitian ini didukung penelitian yang dilakukan oleh Evi Rosita dimana sebanyak $76,4 \%$ responden yang 
melakukan perawatan payudara tidak mengalami bendungan ASI. Breast care atau perawatan payudara juga dapat memperlancar proses laktasi. Gerakan pada perawatan payudara bermanfaat melancarkan reflek pengeluaran ASI dan mencegah bendungan pada payudara (Rosita, 2017)

Masalah yang sering terjadi pada ibu post partum adalah bendungan ASI sehingga hal ini menjadi salah satu penyebab kegagalan pemberian ASI ekslusif. Peran Bidan sangat penting dalam memberikan Konseling, Informasi dan Edukasi tentang teknik perawatan payudara khususnya pada minggu minggu pertama melahirkan sebagai upaya untuk mencegah terjadinya bendungan ASI. Tujuan dari penelitian ini adalah untuk mengetahui hubungan perawatan payudara dalam mencegah bendungan ASI pada ibu post partum.

\section{METODOLOGI PENELITIAN}

Jenis penelitian yang digunakan adalah penelitian deskriptif analitif dengan rancangan penelitian cross sectional. Variabel bebas dapat memengaruhi variabel terikat dimana Variabel bebas pada penelitian ini adalah breast care (perawatan payudara) dan variabel terikat pada penelitian ini adalah bendungan ASI.

Populasi pada penelitian ini adalah seluruh ibu postpartum yang melahirkan normal di Praktik Mandiri Bidan (PMB)
Nurachmi. Sampel pada penelitian ini adalah sebagian ibu postpartum yang melahirkan normal, dan bersedia menjadi responden. Pengambilan sampel dilakukan secara consecutive sampling dimana pemilihan sampel yang dilakukan dengan memilih semua individu yang ditemui dan memenuhi kriteria pemilihan, sampai jumlah sampel yang diinginkan oleh peneliti terpenuhi dengan kriteria sample yaitu yang melahirkan secara normal, bayi aterm, tunggal, dan sehat, berat badan lahir bayi $\geq 2500$ gram, lbu tidak menggunakan obat-obatan lain untuk meningkatkan produksi ASI dan bersedia menjadi responden sehingga didapatkan 30 responden. Analisis data yang dilakukan meliputi analisis univariat dan bivariat. Uji statistik yang digunakan adalah Uji Chi-Square.

\section{HASIL PENELITIAN DAN BAHASAN}

Tabel 1 Distribusi Frekuensi Responden Berdasarkan Pendidikan

\begin{tabular}{lcc}
\hline $\begin{array}{c}\text { Perawatan } \\
\text { payudara }\end{array}$ & $\begin{array}{c}\text { Frekuensi } \\
(\mathfrak{f})\end{array}$ & $\begin{array}{c}\text { Presentase } \\
(\%)\end{array}$ \\
\hline Dilakukan & 21 & 70 \\
Tidak dilakukan & 9 & 30 \\
\hline Jumlah & 30 & $100 \%$ \\
\hline
\end{tabular}

Tabel 1 menunjukkan sebagian besar responden melakukan perawatan payudara dengan jumlah 21 responden (70\%).

Penelitian ini sejalan dengan penelitian yang telah dilakukan oleh 
Suprayitno dkk bahwa sebanyak $76 \%$ ibu menyusui melakukan perawatan payudara yang kurang baik. Perawatan payudara yang teratur dapat diterapkan guna memelihara kebersihan putting susu dan mempelancarpengeluaran ASI.(Suprayitno et al., 2018)

Payudara merupakan salah satu bagian yang harus diperhatikan oleh ibu post partum dikarenakan payudara merupakan organ esensial sebagai penghasil ASI yaitu makanan utama bagi bayi baru lahir sehingga perawatannya harus dilakukan sedini mungkin. lebih besar terjadi bendungan ASI jika dibandingkan ibu yang melakukan perawatan payudara.

Bendungan ASI terjadi dikarenakan aliran vena dan limfatik tersumbat, aliran susu menjadi terhambat dan tekanan pada saluran ASI dan alveoli meningkat. Hal ini biasanya disebabkan karena ASI yang terkumpul tidak dikeluarkan sehingga menjadi sumbatan. Bendungan ASI tersebut dapat dicegah dengan cara perawatan payudara yang dapat dilakukan oleh ibu. ( Rutiani and Fitriana, 2017)

Tabel 2 Hubungan Perawatan Payudara dengan Kejadian Bendungan ASI

\begin{tabular}{|c|c|c|c|c|c|c|c|}
\hline \multirow{3}{*}{ Perawatan Payudara } & \multicolumn{4}{|c|}{ Bendungan ASI } & \multirow{3}{*}{$n$} & \multirow{3}{*}{ OR } & \multirow{3}{*}{$\mathrm{P}$ Value } \\
\hline & \multicolumn{2}{|c|}{ Tidak } & \multicolumn{2}{|c|}{ Iya } & & & \\
\hline & $n$ & $\%$ & $\mathrm{n}$ & $\%$ & & & \\
\hline Dilakukan & 15 & 71,4 & 6 & 28,6 & 21 & & \\
\hline Tidak Dilakukan & 2 & 22,2 & 7 & 77,8 & 7 & 8,75 & 0,02 \\
\hline Jumlah & 17 & 56,7 & 13 & 43,3 & 30 & & \\
\hline
\end{tabular}

Tabel 2 menunjukkan bahwa responden yang melakukan perawatan payudara lebih sedikit mengalami bendungan ASI (28,6\%) dibandingkan dengan responden dengan yang tidak melakukan perawatan payudara $(77,8 \%)$. Dari hasil uji Chi Square didapatkan nilai $p$ value $=0,020(p<0,05)$ sehingga terdapat hubungan perawatan payudara dengan kejadian bendungan ASI pada ibu post partum.

Pada Tabel 2 juga menunjukkan bahwa ibu yang tidak melakukan perawatan payudara berisiko 8,75 kali
Penelitian ini sejalan dengan penelitian sebelumnya, dimana sebelum dilakukan Masase Payudara dari 16 ibu post partum terdapat $81,3 \%$ atau 13 orang ibu post partum yang dikategorikan mengalami bendungan $\mathrm{ASI}$ dan setelah dilakukan Masase Laktasi terjadi penurunan bendungan ASI dari $81,3 \%$ menjadi $18,8 \%$ sehingga terdapat pengaruh masase terhadap bendungan ASI. (Taqiyah et al., 2019)

Penelitian ini juga didukung oleh penelitian sebelumnya dimana ibu nifas yang melakukan perawatan payudara selama menyusui tidak terjadi bendungan 
ASI. Hal ini dikarenakan gerakan pada perawatan payudara akan melancarkan reflek pengeluaran $\mathrm{ASI}$, serta dapat mencegah dan mendeteksi dini kemungkinan adanya bendungan ASI dapat berjalan lancar. (Rosita, 2017)

Selama laktasi terjadi peningkatan produksi ASI pada ibu yang berlebihan. Apabila bayi sudah kenyang dan selesai menyusui dan payudara tidak dikosongkan maka masih terdapat sisa ASI dalam payudara. Sisa ASI tersebut jika tidak di keluarkan dapat menimbulkan bendungan ASI. Payudara yang mengalami pembengkakan atau bendungan $\mathrm{ASI}$ tersebut sangat sukar disusu oleh bayi karena payudara lebih menonjol, puting lebih datar, dan sukar di hisap oleh bayi, bila keadaan sudah demikian, payudara akan mengkilat ibu merasa demam dan payudara terasa nyeri (Impartina, 2017)

Menyusui memberikan manfaat untuk ibu dan bayinya. Secara Fisiologis Produksi ASI yang cukup terjadi pada hari ke-dua atau ketiga sampai 8 hari post partum. Timbulnya sekresi susu yang berlimpah hal ini ditandai dengan payudara menjadi sangat penuh disebut dengan Lactogenesis II, namun keadaan ini bisa menyebabkan bendungan ASI jika pengosongan ASI tidak sempurna. (Gustirini, 2018)

Bendungan ASI dapat terjadi jika pengosongan ASI tidak sempurna. Hal ini dikarenakan Aliran limfotik akan tersumbat sehingga aliran susu menjadi terhambat, payudara akan terbendung, membesar, membengkak, dan sangat nyeri, puting susu akan teregang menjadi rata, ASI tidak mengalir dengan mudah dan bayi akan sulit mengenyut untuk menghisap ASI. (Taqiyah et al., 2019)

Perawatan payudara selain untuk mencegah terjadinya bendungan ASI, juga dapat meningkatkan produksi ASI dengan merangsang kelenjar - kelenjar air susu melalui teknik pemijatan. (Wulan and Gurusinga, 2017)

\section{KESIMPULAN}

Perawatan payudara yang teratur pada ibu post partum dapat mencegah kejadian bendungan ASI, sehingga dibutuhkan peran bidan sebagai care provider guna memberikan Konseling, Informasi dan Edukasi kepada ibu post partum tentang pentingnya perawatan payudara sedini mungkin. Bidan dapat mengajarkan langkah-langkah melakukan perawatan payudara sampai ibu mengerti, memahami dan mampu melakukan perawatan secara mandiri.

\section{DAFTAR PUSTAKA}

1. Dinas Kesehatan 2014. Profil Kesehatan Kota Palembang. 1-210.

2. Gustirini, R. 2018. Hubungan Antara Berat Badan Lahir Bayi Dengan Waktu Terjadinya Lactogenesis II Pada Ibu Postpartum. Masker Medika, 6, 472-479.

3. Gustirini, R. \& Anggraini, I. A. 2020. Combination Of Breast Care And Oxytocin Massage Of Breastfeeding 
Mothers In Infant Weight Gain. Jurnal Kesehatan Prima, 14, 24-30.

4. Impartina, A. 2017. Hubungan Pengetahuan lbu Nifas Tentang Teknik Menyusui Dengan Kejadian Bendungan ASI. Medisains, 15, 156160.

5. Kementrian Kesehatan Republik Indonesia. 2013. Profil Kesehatan Indonesia.

6. Kemenkes 2012. Survey Dasar Kesehatan Indonesia.

7. Lamberti, L. M., Walker, C. L. F., Noiman, A., Victora, C. \& Black, R. E. 2011. Breastfeeding and the risk for diarrhea morbidity and mortality. BMC public health, 11, S15.

8. Murniati, R. \& Kusumawati, E. 2013. hubungan pengetahuan ibu nifas tentang bendungan ASI dengan praktik pencegahan bendungan ASI (breast care) di RB Nur Hikmah Kwaron Gubug. Jurnal Kebidanan, 2.

9. Rosita, E. 2017. Hubungan Perawatan Payudara Pada lbu Nifas Dengan Bendungan ASI (Studi Di Desa Jolotundo dan Desa Kupang Kecamatan Jetis Kabupaten Mojokerto). Jurnal Kebidanan, 7.

10. Rutiani, C. E. A. \& Fitriana, L. A. 2017. Gambaran bendungan ASI pada ibu nifas dengan seksio sesarea berdasarkan karakteristik di rumah sakit Sariningsih Bandung. Jurnal Pendidikan Keperawatan Indonesia, 2, 146-155.

11. Suprayitno, E., Pratiwi, I. G. D. \& Yasin, Z. 2018. Gambaran Penyebab Terjadinya Pembengkakan Payudara Pada Ibu Menyusui Di Polindes Desa Meddelen Kecamatan Lenteng. Wiraraja Medika, 8, 13-18.

12. Taqiyah, Y., Sunarti, S. \& Rais, N. F. 2019. Pengaruh perawatan payudara terhadap bendungan asi pada ibu post partum di Rsia Khadijah I Makassar. Journal of Islamic Nursing, 4, 12-16.
13. Wulan, S. \& Gurusinga, R. 2017. Pengaruh Perawatan Payudara (Breast Care) terhadap Volume ASI pada lbu Post Partum (Nifas) di RSUD Deli Serdang Sumut Tahun 2012. Jurnal Kebidanan Harapan Ibu Pekalongan, 1, 21-24.

14. Wulandari, F. T., Aminin, F. \& Dewi, U. 2016. Pengaruh pijat oksitosin terhadap pengeluaran kolostrum pada ibu post partum di Rumah Sakit Umum Daerah Provinsi Kepulauan Riau. Jurnal Kesehatan, 5. 